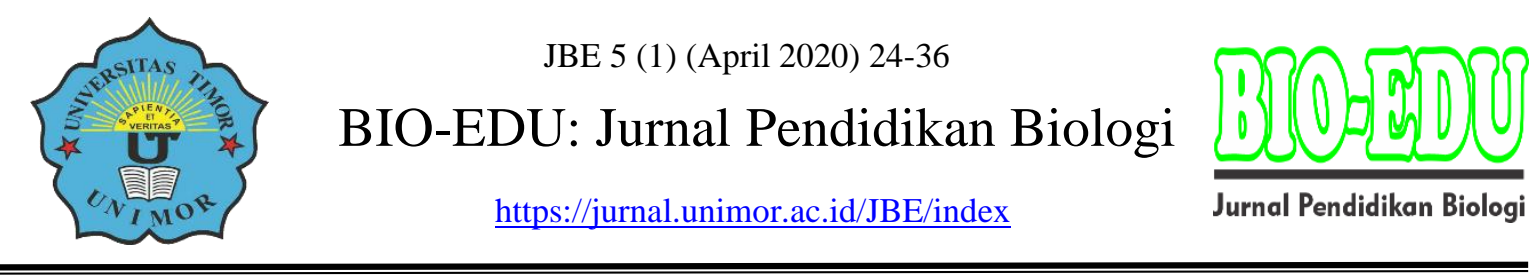

\title{
Analisis Is Structure and Vegetation Composition Increases Tree and Pillar At Hutan Lindung Oereu Village Bani Bani Is Io Kufeudistrict Malacca Regency
}

\section{Analisis Struktur dan Komposisi Vegetasi Tingkat Pohon dan Tiang Di Hutan Lindung Oereu Desa Bani-Bani Kecamatan Io Kufeu Kabupaten Malaka}

\author{
ANGELA NIIS \\ Fakultas Ilmu Pendidikan, Universitas Timor, Kefamenanu, TTU - NTT, 85613, Indonesia \\ Email: angelaniis@gmail.com
}

DOI: https://doi.org/10.32938/jbe.v5i1.531

\begin{abstract}
Abstrak
Tujuan dari penelitian ini adalah Untuk mengetahui jenis tumbuhan tingkat pohon dan tiang yang terdapat di hutan Lindung Oereu Desa Bani-Bani Kecamatan Io Kufeu Kabupaten Malaka,Untuk mengetahui struktur dan komposisi vegetasi tumbuhan tingkat pohon dan tiang yang terdapat di hutan Lindung Oereu Desa Bani-Bani Kecamatan Io Kufeu Kabupaten Malaka, dan Untuk mengimplementasikan penelitian struktur dan komposisi vegetasi tingkat pohon dan tiang di hutan Lindung Oereu Desa Bani-Bani Kecamatan Io Kufeu Kabupaten Malaka dalam pembelajaran biologi di sekolah. Metode yang digunakan dalam penelitian ini adalah metode kuadrat dengan penempatan plot disamping garis transek. Pada setiap garis transek di letakkan plot-plot pengamatan sebanyak 5 plot dengan ukuran masing-masing plot $20 \mathrm{~m} \mathrm{x} 20 \mathrm{~m}=400 \mathrm{~m}^{2}$ untuk tingkat pohon, dan $10 \mathrm{~m} \mathrm{x} 10 \mathrm{~m}=100 \mathrm{~m}^{2}$ untuk tingkat tiang, dengan jarak antara plot $25 \mathrm{~m}$.Untuk menganalisis struktur dan komposisi vegetasi tingkat pohon, dan tiang yang ditemukan di lokasi penlitian yaitu dengan menghitung densitas mutlak, densitas relatif, frekuensi mutlak, frekuensi relatif, luas basal area, luas basal area relatif, dan indeks nilai penting. Hasil penelitian ditemukannya sebanyak 13 jenis tumbuhan yang terdiri dari 11 famili. Apabila dilihat indeks nilai penting pada vegetasi tingkat pohon, indeks nilai penting tertinggi adalah Tectona grandis, $L, 57,35 \%$, sedangkan yang mempunyai indeks nilai penting terendah adalah Alstonia scholaris, $L$ $13,22 \%$, Dan pada vegetasi tingkat tiang, indeks nilai penting tertinggi adalah Tectona grandis, L, 36,33\%, sedangkan yang mempunyai indeks nilai penting terendah adalah Leucena lenccophalla, 16,25\%. Jenis vegetasi yang mempunyai indeks nilai penting tertinggi disebabkan karena memiliki kemampuan penyebaran yang cukup tinggi dan dapat beradaptasi baik dengan lingkungannya.
\end{abstract}

Kata kunci : Analisis, Vegetasi, Struktur, Komposisi, Pohon, Tiang, Hutan Lindung Oereu

Abstract
The purpose of this study was to determine the tree and pole-level plant species found in the Oereu Protected
Forest Bani-Bani Village Io Kufeu District of Malacca District, To find out the structure and composition of
tree-level plant vegetation and poles found in the Oereu Protected Forest in the Bani-Bani Village District of Io
Kufeu District of Malacca, and To implement research on the structure and composition of tree and pole level 
vegetation in the Oereu Protection Forest of Desa Bani-Bani District of Io Kufeu District of Malacca in learning biology in schools. The method used in this study is the quadratic method by placing a plot beside the transect line. At each transect line, 5 observation plots were placed with the size of each plot $20 \mathrm{mx} 20 \mathrm{~m}=400 \mathrm{~m} 2$ for tree level, and $10 \mathrm{mx} 10 \mathrm{~m}=100 \mathrm{~m} 2$ for pole level, with a distance between plots $25 \mathrm{~m}$. analyzing the structure and composition of tree-level vegetation, and poles found at research sites, namely by calculating absolute density, relative density, absolute frequency, relative frequency, basal area, relative basal area, and important value index. The results of the study were found as many as 13 types of plants consisting of 11 families. When looking at the importance value index at tree level vegetation, the highest important value index is Tectona grandis, L, 57.35\%, while the one with the lowest important value index is Alstonia scholaris, L $13.22 \%$, and at pole level vegetation, the index value the highest importance is Tectona grandis, L, 36.33\%, while the one with the lowest important value index is Leucena lenccophalla, $16.25 \%$. The type of vegetation that has the highest important value index is because it has a fairly high distribution ability and can adapt well to its environment.

Keywords: Analysis, Vegetation, Structure, Composition, Trees, Poles, Oereu Protection Forest

\section{PENDAHULUAN}

Indonesia merupakan salah satu negara yang memiliki kekayaan sumberdaya hutan dan keanekaragaman hayati yang beragam. Hutan Indonesia merupakan salah satu hutan tropis yang terbesar di dunia. Hal ini disebabkan karena sebagian hutan di Indonesia termasuk dalam hutan tropis yang memiliki tumbuhan yang sangat kompleks dan sebagai tempat menyediakan pohon dari berbagai ukuran serta makhluk hidup lain yang berada didalamnya.

Secara umum hutan memiliki peranan penting bagi kehidupan yaitu: menyelenggarakan suatu keseimbangan oksigen di udara menjaga kelestarian sumber air tanah, sebagai suatu alam yang melestarikan tumbuhan dan hewan langka. Untuk ilmu pengetahuan, kebudayaan, estetika dan rekreasi serta mempunyai peranan penting dalam menjaga agar terpenuhinya kebutuhan -kebutuhan dasar untuk kelangsungan hidup hayati, berupa air, udara dan pangan (Anonimus, 1995).

Kawasan Hutan Lindung Oereu terletak di Desa Bani-Bani Kecamatan Io Kufeu, merupakan kawasan hutan lindung yang di dalamnya terdapat keanekaragaman flora dan fauna beserta tempat-tempat ritual adat. Hutan Oereu merupakan hutan musiman yang tahan akan kekeringan atau hutan musiman yang dari pohon-pohon yang tergolong tumbuhan tropofita yaitu pada musim kemarau daunnya meranggas dan menghijau kembali pada musim hujan. Hutan musim ini ditandai dengan adanya pohon-pohon yang tinggi dan jumlah individu lain yang dapat dimanfaatkan oleh masyarakat setempat. Hutan ini hanya memiliki satu lapisan tajuk atau stratum dengan tajuk-tajuk pohon dan tiang yang saling tumpang tindih sehingga masih ada sinar matahari yang masuk kedalam hutan. Hutan tersebut juga memiliki keanekaragaman pohon dan tiang yang tinggi, pohon dan tiang tersebut memegang peran yang sangat penting dalam komunitas hutan dan berfungsi sebagai penyangga kehidupan, baik dalam mencegah erosi dan menjaga stabilitas iklim

Hutan Lindung Oereu sering mengalami kerusakan karena disebabkan oleh aktivitas manusia dalam pendayagunaan sumberdaya alam seperti: penebangan pohon dan tiang untuk keperluan ekonomi dan pembangunan. Oleh karena itu untuk menjaga kelestarian hutan Lindung Oereu khususnya tingkat pohon dan tiang maka perlu untuk diketahui tentang setiap jenis tumbuhan yang hidup sehingga memungkinkan masyarakat dapat dengan mudah untuk memanfaatkan potensi tumbuhan dengan tidak merusak ekosistem yang ada, sehingga perlu untuk mengetahui analisis struktur dan komposisi vegetasi tingkat pohon dan tiang tersebut. 
Hutan merupakan kumpulan pepohonan yang tumbuh rapat beserta tumbuhtumbuhan yang memanjat dengan bunga yang beraneka warna yang berperan sangat penting bagi kehidupan dibumi ini. Hutan juga merupakan suatu assosiasi dari tumbuh-tumbuhan yang sebagian besar terdiri atas pohon-pohon atau vegetasi berkayu yang menepati areal luas. Hutan juga sebagai masyarakat yang di kuasai oleh pohon-pohon dan mempunyai keadaan lingkungan yang berbeda dengan eadaan luar di hutan. Di dalam hutan jugan akan terjadi persaingan antar angota-angota yang hidup saling berdekatan, misalnya dalam persaingan unsur hara, air, sinar matahari, ataupun tempat tumbuh. Persaingan ini hanya tidak terjadi pada tumbuhan saja tetapi juga pada binatang (Arief, 2001).

Hutan juga memiliki manfaat bagi manusia Manfaat hutan tersebut diperoleh apabila hutan terjamin ekosistemnya sehingga dapat berfungsi secara optimal. Maanfaat hutan secara tidak langsung meliputi fungsi-fungsi ekologi seperti memperbaiki atmosfer dengan penyediaan oksigen, memperbaiki lingkungan hidup dalam berbagai bentuk misalnya mencegah terjadinya tanah longsor dengan menahan air hujan, serta menjadi tempat tinggal beberapa jenis tanaman dan binatang tertentu yang tidak bisa hidup di tempat lainnya. Manfaat hutan secara langsung dapat berupa fungsi ekonomi dan sosial dari hutan yang memberikan peran nyata apabila pengelolaan sumber daya alam berupa hutan seiring dengan pelestarian guna mewujudkan pembangunan nasional berkelanjutan (Zain,1992).

\section{Strata Pertumbuhan Pohon dan Tiang}

Menurut Sutarno dan Soedarsono (1997), pohon hutan merupakan tumbuhan yang berperawakan pohon, batangnya tunggal berkayu, tegak biasanya beberapa meter dari tanah tidak bercabang, mempunyai tajuk dengan percabangan dan daun. Menurut Whitmore (1986) dalam Tamin (1991), pohon tumbuh serta alami di hutan dalam bentuk yang dominan, bahkan tumbuhan bawah sebagian besarnya terdiri dari tumbuhan berkayu yang mempunyai bentuk pohon.

Tumbuhan tingkat tiang merupakan salah satu anggota komunitas hutan yang sangat berperan dalam ekosistem, yang perlu diperhatikan dalam rencana konservasi hutan, kehadiran dan pola penyebaran serta bentuk vegetasi tumbuhan tingkat tiang memiliki peran penting dalam kehidupan manusia. Tumbuhan Tiang merupakan pohon mudah yang keliling batang atau diameternya 10-20 cm (Indriyanto, 2008).

\section{METODE}

\section{Lokasi dan Waktu Penelitian}

Penelitian ini telah dilaksanakan di hutan Lindung Oereu Desa Bani-bani Kecamatan Io Kufeu Kabupaten Malaka, pada Bulan Juli 2017.

\section{Teknik Penelitian}

Teknik yang digunakan dalam penelitian ini adalah teknik kuadrat.

\section{Alat dan Bahan}


Alat dan bahan yang digunakan dalam penelitian ini adalah sebagai berikut: meter roll, tali raffia, kamera, parang, kayu patok, alat tulis.

\section{Prosedur Pengambilan Data}

Prosedur atau cara kerja sebagai berikut:

1. Melakukan observasi di lokasi penelitian, untuk mendapatkan gambaran umum tentang Hutan Lindung Oereu

2. Menentukan batas daerah penelitian dengan luas lokasi penelitian sebesar $2 \mathrm{Ha}$.

3. Membuat garis transek sebanyak 3 (tiga) transek dengan panjang garis transek $200 \mathrm{~m}$ dan jarak antara transek $50 \mathrm{~m}$.

4. Pada setiap garis transek di letakkan plot-plot pengamatan sebanyak 5 plot dengan ukuran masing-masing plot $20 \mathrm{~m}$ x $20 \mathrm{~m}=400 \mathrm{~m}^{2}$ untuk tingkat pohon, dan $10 \mathrm{~m} \times 10 \mathrm{~m}=100$ $\mathrm{m}^{2}$ untuk tingkat tiang, dengan jarak antara plot $25 \mathrm{~m}$.

5. Penentuan struktur vegetasi didasarkan pada distribusi individu dan basal area masingmasing tegakan pada berbagai kelas diameter. Penentuan pohon dan tiang ditentukan dengan cara menghitung dan mengukur diameter batang setinggi dada atau tinggi $150 \mathrm{~cm}$. pengukuran basal area setiap jenis di tentukan rumus:

$$
\text { b. } a=(1 / 4 d)^{2} \cdot \pi
$$

Dimana; b.a = basal area, $\mathrm{d}=$ diameter batang.

Untuk mendapatkan diameter batang maka data keliling batang dikonversikan dengan rumus:

$$
\mathrm{d}=\frac{\text { keliling batang }}{\pi}
$$

Dimana; $\pi=3,14$ (konstanta)

\section{Analisis Data}

Untuk mendapat struktur vegetasi pohon dan tiang, suatu vegetasi maka digunakan rumus sebagai berikut:

1. Densitas mutlak

2. Densitas relatif

3. Frekuensi mutlak

4. Frekuensi relatif

5. Luas basal area

6. Luas basal area relatif
: $\frac{\text { jumlah cacah individu }}{\text { luasarea kajian }(\mathrm{Ha})}$

$: \frac{\text { densitas spesies } A}{\text { densitas total }} \times 100 \%$

: $\frac{\text { jumlah plot ditemukannya spesies } A}{\text { jumlah semua titik sampling }}$

: $\frac{\text { frekuensispesies } A}{\text { frekuensi total }} \times 100 \%$

: $\frac{\text { jumlah basal area spesies } A}{\text { luas basal area total }}$

$: \frac{\text { luas basal area spesies } A}{\text { Luas basal area total }} \times 100 \%$

(INP) diperoleh dari penjumlahan densitas relatife (DR), Frekuensi relatif (FR), dan Luas basal area relatif (LBAR) dengan rumus: 


$$
\mathrm{INP}=\mathrm{DR}+\mathrm{FR}+\mathrm{LBAR}
$$

\section{HASIL DAN PEMBAHASAN}

\section{Jenis-Jenis Vegetasi tingkat Pohon dan Tiang yang ditemukan di Lokasi Penelitian}

Hasil penelitian tentang Analisis Struktur Dan Komposisi Vegetasi Tingkat Pohon Dan Tiang Di Hutan Lindung Oereu, Desa Bani-Bani Kecamatan Io Kufeu, Kabupaten Malaka dapat dilihat pada tabel 1.

Tabel 1. Daftar Jenis Tumbuhan yang Ditemukan di Lokasi Penelitian

\begin{tabular}{|c|l|l|l|l|l|}
\hline No & $\begin{array}{l}\text { Nama } \\
\text { Local }\end{array}$ & $\begin{array}{l}\text { Nama } \\
\text { Indonesia }\end{array}$ & Nama Ilmiah & Nama Family & Habitus \\
\hline 1 & Karuya & Johar & Cassia siamea, $L$ & Mimocaceae & Pohon, tiang \\
\hline 2 & Jati & Jati & Tectona grandis, $L$ & Verbanaceae & Pohon, tiang \\
\hline 3 & Mahoni & Mahoni & Swietenia macrophylla & Miliaceae & Pohon, tiang \\
\hline 4 & Akasia & Akasia & Acacia mangium, $L$ & Mimocaceae & Pohon, tiang \\
\hline 5 & Beaska & Kabesak & $\begin{array}{l}\text { Zyziphus mauritiana, } \\
\text { Dryand }\end{array}$ & Rhamnaceae & Pohon, tiang \\
\hline 6 & Up fui & Mangga hutan & Mangifera indica, $L$ & Anacardiaceae & Pohon, tiang \\
\hline 7 & Usapi & Kusambi & Schleichera oleasa, Merr & Sapindaceae & Pohon, tiang \\
\hline 8 & Lantora & Lamtoro & Leucena lenccophalla & Mimocaceae & Pohon, tiang \\
\hline 9 & Niatsa & Pohon nitas & Bombax ceiba, $L$ & Bombaceae & Pohon, tiang \\
\hline 10 & Nunha & Beringin & Ficus benjamina, $L$ & Maraceae & Pohon, tiang \\
\hline 11 & Rete & Pohon roti & Alstonia scholaris, $L$ & Apocynaceae & Pohon, tiang \\
\hline 12 & Ai yoa & Cemara & $\begin{array}{l}\text { Casuarinas } \\
\text { junghuhyniana, } \text { Miq }\end{array}$ & Casuarinaceae & Pohon, tiang \\
\hline 13 & Hue'ka & Pohon putih & Zyziphus jujube, Mill & $\begin{array}{l}\text { Zhyziphus } \\
\text { jujube, Mill }\end{array}$ & Pohon, tiang \\
\hline
\end{tabular}

Struktur dan Komposisi Vegetasi Tingkat Pohon dan Tiang

Struktur vegetasi tingkat pohon dan tiang dapat di lihat pada tabel 2

Tabel 2. Struktur Vegetasi Tingkat Pohon dan Tiang di Lokasi Penelitian

\begin{tabular}{|c|l|c|c|c|}
\hline \multirow{2}{*}{ No } & \multirow{2}{*}{ Jenis Tumbuhan } & \multicolumn{3}{|c|}{ Jumlah Individu Tiap Tingkatan } \\
\cline { 3 - 5 } & & Pohon & Tiang & Jumlah Total Individu \\
\hline 1 & Cassia siamea, $L$ & 17 & 8 & 25 \\
\hline 2 & Tectona grandis, $L$ & 35 & 15 & 50 \\
\hline 3 & Swietenia macrophylla & 21 & 9 & 30 \\
\hline 4 & Acacia mangium, $L$ & 9 & 6 & 15 \\
\hline 5 & $\begin{array}{l}\text { Zyziphus mauritiana, } \\
\text { Dryand }\end{array}$ & 4 & 2 & 6 \\
\hline
\end{tabular}




\begin{tabular}{|c|c|c|c|c|}
\hline 6 & Mangifera indica, $L$ & 5 & 2 & 7 \\
\hline 7 & Schleichera oleasa, Merr & 5 & 3 & 8 \\
\hline 8 & Leucena lenccophalla & 6 & 2 & 8 \\
\hline 9 & Bombax ceiba, $L$ & 7 & 3 & 10 \\
\hline 10 & Ficus benjamina, $L$ & 4 & 2 & 6 \\
\hline 11 & Alstonia scholaris, $L$ & 4 & 5 & 9 \\
\hline 12 & $\begin{array}{l}\text { Casuarinas } \\
\text { junghuhyniana, Miq }\end{array}$ & 7 & 5 & 12 \\
\hline 13 & Zyziphus jujube, Mill & 6 & 4 & 10 \\
\hline & JUMLAH & 130 & 66 & 196 \\
\hline
\end{tabular}

Berdasarkan data pada tabel 2 menunjukkan bahwa jenis tumbuhan yang memiliki jumlah individu yang banyak di temukan di lokasi penelitian adalah Tectona grandis, $L$ Dengan jumlah 50 individu dan yang paling sedikit adalah Ficus benjamina, L Dengan jumlah 4 individu.

\section{Vegetasi Tingkat Pohon}

Hasil perhitungan densitas mutlak dan densitas relatif jenis tumbuhan tingkat pohon di lokasi penelitian dapat di lihat pada tabel 3.

Tabel 3. Nilai Densitas Mutlak dan Densitas Relatif Jenis Tumbuhan Tingkat Pohon di Lokasi Penelitian

\begin{tabular}{|c|c|c|c|c|}
\hline No & Jenis Tumbuhan & $\begin{array}{l}\text { Jumlah } \\
\text { Individu }\end{array}$ & $\begin{array}{c}\text { Densitas } \\
\text { Mutlak }\left(\mathbf{M}^{2}\right) \\
\end{array}$ & $\begin{array}{c}\text { Densitas } \\
\text { Relatif }(\%)\end{array}$ \\
\hline 1 & Cassia siamea, $L$ & 17 & 0,04 & 14,29 \\
\hline 2 & Tectona grandis, $L$ & 35 & 0,08 & 28,58 \\
\hline 3 & Swietenia macrophylla & 21 & 0,05 & 17,86 \\
\hline 4 & Acacia mangium, $L$ & 9 & 0,02 & 7,14 \\
\hline 5 & Zyziphus mauritiana, Dryand & 4 & 0,01 & 3,57 \\
\hline 6 & Mangifera indica, $L$ & 5 & 0,01 & 3,57 \\
\hline 7 & Schleichera oleasa, Merr & 5 & 0,01 & 3,57 \\
\hline 8 & Leucena lenccophalla & 6 & 0,01 & 3.57 \\
\hline 9 & Bombax ceiba, $L$ & 7 & 0,01 & 3,57 \\
\hline 10 & Ficus benjamina, $L$ & 4 & 0,01 & 3,57 \\
\hline 11 & Alstonia scholaris, $L$ & 4 & 0,01 & 3,57 \\
\hline 12 & Casuarinas junghuhyniana, Miq & 7 & 0,01 & 3,57 \\
\hline 13 & Zyziphus jujube, Mill & 6 & 0,01 & 3,57 \\
\hline & JUMLAH & 130 & $\mathbf{0 , 2 8}$ & 100 \\
\hline
\end{tabular}

Berdasarkan data pada tabel 3 menunjukkan bahwa jenis tumbuhan tingkat pohon yang mempunyai nilai densitas relatif tertinggi adalah Tectona grandis, L. Dengan nilai 
densitas 28,58 \%, kemudian diikuti oleh Swietenia macrophylla. Dengan nilai densitas 17,86 $\%$, Cassia siamea, L. Dengan nilai densitas 14,29\%. Dengan nilai densitas Acacia mangium, $L$. Dengan nilai densitas 7,14 \%, Dan jenis lain yang mempunyai nilai densitas sama yaitu: Bombax ceiba, L. Casuarinas junghuhyniana, Miq. Schleichera oleasa, Merr., Mangifera indica, L., Alstonia scholaris, L., Zyziphus mauritiana, Dryand., Leucena lenccophalla., Ficus benjamina, L., Zyziphus jujube, Mill. Dengan nilai densitas 3,57 \%.

Nilai Frekuensi Mutlak dan Frekuensi Relatif Jenis Tumbuhan Tingkat Pohon

Berdasarkan nilai frekuensi pada tabel 3 diketahui bahwa jenis tumbuhan tingkat pohon yang mempunyai nilai frekuensi relatif adalah Tectona grandis, L. Dengan nilai frekuensi 20,42 \%, kemudian diikuti oleh Cassia siamea, $L$. Dengan nilai frekuensi 17,14 \%, Swietenia macrophylla. Dengan nilai frekuensi 12,44\%, Acacia mangium, L Dengan nilai frekuensi 9,39\%, Dan jenis lain yang mempunyai nilai frekuensi sama yaitu: Leucena lenccophalla, Casuarinas junghuhyniana, Miq. Dengan nilai frekuensi 6,33 \%, Zyziphus mauritiana, Dryand, Schleichera oleasa, Merr. Bombax ceiba, L. Zyziphus jujube, Mill Dengan nilai frekuensi 4,70\%, Mangifera indica. L, Ficus benjamina, L, Alstonia scholaris, L. Dengan nilai frekuensi $3,05 \%$.

Hasil perhitungan nilai frekuensi mutlak dan frekuensi relatif jenis tumbuhan tingkat pohon dapat di lihat pada tabel 4 .

Tabel 4. Nilai Frekuensi Mutlak dan frekuensi Relatif Jenis Tumbuhan Tingkat Pohon di Lokasi Penelitian.

\begin{tabular}{|c|l|c|c|c|}
\hline No & \multicolumn{1}{|c|}{ Jenis Tumbuhan } & $\begin{array}{c}\text { Jumlah } \\
\text { Individu }\end{array}$ & $\begin{array}{c}\text { Frekuensi } \\
\text { Mutlak } \\
\left(\mathbf{M}^{2}\right)\end{array}$ & $\begin{array}{c}\text { Frekuensi } \\
\text { Relatif }(\%)\end{array}$ \\
\hline 1 & Cassia siamea, $L$ & 11 & 0,73 & 17,14 \\
\hline 2 & Tectona grandis, $L$ & 13 & 0,87 & 20,42 \\
\hline 3 & Swietenia macrophylla & 8 & 0,53 & 12,44 \\
\hline 4 & Acacia mangium, L & 6 & 0,4 & 9,39 \\
\hline 5 & Zyziphus mauritiana, Dryand & 3 & 0,2 & 4,70 \\
\hline 6 & Mangifera indica, L & 2 & 0,13 & 3,05 \\
\hline 7 & Schleichera oleasa, Merr & 3 & 0,2 & 4,70 \\
\hline 8 & Leucena lenccophalla & 4 & 0,27 & 6,33 \\
\hline 9 & Bombax ceiba, L & 3 & 0,2 & 4,70 \\
\hline 10 & Ficus benjamina, L & 2 & 0,13 & 3,05 \\
\hline 11 & Alstonia scholaris, L & 2 & 0,13 & 3,05 \\
\hline 12 & Casuarinas junghuhyniana, Miq & 4 & 0,27 & 6,33 \\
\hline 13 & Zyziphus jujube, Mill & 3 & 0,2 & 4,70 \\
\hline & $\quad$ JUMLAH & $\mathbf{6 4}$ & $\mathbf{4 , 2 6}$ & $\mathbf{1 0 0}$ \\
\hline
\end{tabular}




\section{Nilai Luas Basal Area Dan Luas Basal Area Relatif Jenis Tumbuhan Tingkat Pohon}

Berdasarkan hasil perhitungan pada tabel 5 menunjukkan bahwa jenis tumbuhan tingkat pohon yang mempunyai nilai basal area relatif tertinggi adalah Bombax ceiba, L 11,75 $\%$ kemudian diikuti oleh Zyziphus mauritiana, Dryand, Ficus benjamina, L, Dengan nilai basal area relatif 10,32 \%, Tectona grandis, L, Casuarinas junghuhyniana, Miq, , Dengan nilai basal area relatif 8,35\%, Schleichera oleasa, Merr, Dengan nilai basal area relatif 7,76 $\%$, Acacia mangium, L, Mangifera indica, L, Dengan nilai basal area relatif 7,17 \%, Alstonia scholaris, $L$, Dengan nilai basal area relatif 6,60\%, Cassia siamea, L, Dengan nilai basal area relatif 6,06 \%, Leucena lenccophalla, Zyziphus jujube, Mill, Dengan nilai basal area relatif 5,55 \%, Swietenia macrophylla, Dengan nilai basal area relatif 5,05\%.

Hasil perhitungan luas basal area relatif jenis tumbuhan tingkat pohon di lokasi penelitian dapat di lihat pada tabel 5 .

Tabel 5. Nilai perhitungan luas basal area relatif jenis tumbuhan tingkat pohon di lokasi penelitian

\begin{tabular}{|c|l|c|c|c|}
\hline No & \multicolumn{1}{|c|}{ Jenis Tumbuhan } & $\begin{array}{c}\text { Jumlah } \\
\text { individu }\end{array}$ & $\begin{array}{c}\text { Luas Basal } \\
\text { Area }\end{array}$ & $\begin{array}{c}\text { Luas Basal } \\
\text { Area Relatif }\end{array}$ \\
\hline 1 & Cassia siamea, $L$ & 17 & 42,06 & 6,06 \\
\hline 2 & Tectona grandis, $L$ & 35 & 57,92 & 8,35 \\
\hline 3 & Swietenia macrophylla & 21 & 35,02 & 5,05 \\
\hline 4 & Acacia mangium, $L$ & 9 & 49,73 & 7,17 \\
\hline 5 & Zyziphus mauritiana, Dryand & 4 & 71,60 & 10,32 \\
\hline 6 & Mangifera indica, L & 5 & 49,73 & 7,17 \\
\hline 7 & Schleichera oleasa, Merr & 5 & 53,81 & 7,76 \\
\hline 8 & Leucena lenccophalla & 6 & 38,46 & 5,55 \\
\hline 9 & Bombax ceiba, L & 7 & 81,51 & 11,75 \\
\hline 10 & Ficus benjamina, L & 4 & 71,60 & 10,32 \\
\hline 11 & Alstonia scholaris, L & 4 & 45,82 & 6,60 \\
\hline 12 & Casuarinas junghuhyniana, Miq & 7 & 57,92 & 8,35 \\
\hline 13 & Zyziphus jujube, Mill & 6 & 38,46 & 5,55 \\
\hline & & $\mathbf{1 3 0}$ & $\mathbf{6 9 3 , 6 4}$ & $\mathbf{1 0 0}$ \\
\hline
\end{tabular}

Indeks Nilai Penting (INP) Tingkat Pohon. Hasil perhitungan indeks nilai penting jenis tumbuhan tingkat pohon dapat di lihat pada tabel 6.

Tabel 6. Hasil perhitungan indeks nilai penting (INP) jenis tumbuhan tingkat pohon di lokasi penelitian

\begin{tabular}{|l|l|c|c|c|c|}
\hline No & \multicolumn{1}{|c|}{ Jenis Tumbuhan } & DR & F R & LBAR & INP $(\%)$ \\
\hline 1 & Cassia siamea, $L$ & 14,29 & 17,14 & 6,06 & 37,49 \\
\hline 2 & Tectona grandis, $L$ & 28,58 & 20,42 & 8,35 & 57,35 \\
\hline 3 & Swietenia macrophylla & 17,86 & 12,44 & 5,05 & 35,35 \\
\hline 4 & Acacia mangium, $L$ & 7,14 & 9,39 & 7,17 & 23,7 \\
\hline 5 & Zyziphus mauritiana, Dryand & 3,57 & 4,70 & 10,32 & 18,59 \\
\hline
\end{tabular}




\begin{tabular}{|l|l|c|c|c|l|}
\hline 6 & Mangifera indica, $L$ & 3,57 & 3,05 & 7,17 & 13,79 \\
\hline 7 & Schleichera oleasa, Merr & 3,57 & 4,70 & 10,32 & 16,03 \\
\hline 8 & Leucena lenccophalla & 3,57 & 6,33 & 5,55 & 15,45 \\
\hline 9 & Bombax ceiba, $L$ & 3,57 & 4,70 & 11,75 & 20,02 \\
\hline 10 & Ficus benjamina, $L$ & 3,57 & 3,05 & 10,32 & 16,94 \\
\hline 11 & Alstonia scholaris, L & 3,57 & 3,05 & 6,60 & 13,22 \\
\hline 12 & $\begin{array}{l}\text { Casuarinas junghuhyniana, } \\
\text { Miq }\end{array}$ & 3,57 & 6,33 & 8,35 & 18,25 \\
\hline 13 & Zyziphus jujube, Mill & 3,57 & 4,70 & 5,55 & 13,82 \\
\hline & JUMLAH & $\mathbf{1 0 0}$ & $\mathbf{1 0 0}$ & $\mathbf{1 0 0}$ & $\mathbf{3 0 0}$ \\
\hline
\end{tabular}

Berdasarkan hasil perhitungan indeks nilai penting pada tabel 6 dapat diketahui bahwa jenis tumbuhan tingkat pohon yang memiliki indeks nilai penting (INP) tertinggi sampai terendah adalah Tectona grandis, L, 57,35\%, Cassia siamea, L,37,49\%, Swietenia macrophylla,35,35 \%, Bombax ceiba, L, 23,7 \%, Acacia mangium, L,20,02 \%, Zyziphus mauritiana, Dryand, 18,59 \%, Casuarinas junghuhyniana, Miq, 18,25 \%, Ficus benjamina, L, 16,94 \%, Schleichera oleasa, Merr, 16,03 \%, Leucena lenccophalla, 15,45 \%, Mangifera indica, L, 13,82 \%, Zyziphus jujube,Mill,13,79\%, Alstonia scholaris, L,13,22 \%

\section{Vegetasi Tingkat Tiang}

\section{Nilai Densitas Mutlak dan Densitas Relatif Jenis Tumbuhan Tingkat Tiang}

Hasil perhitungan densitas mutlak dan densitas relatif jenis tumbuhan tingkat Tiang di lokasi penelitian dapat di lihat pada tabel 7.

Tabel 7. Nilai Densitas Mutlak dan Densitas Relatif Jenis Tumbuhan Tingkat Tiang Di lokasi Penelitian.

\begin{tabular}{|c|l|c|c|c|}
\hline No & \multicolumn{1}{|c|}{ Jenis Tumbuhan } & $\begin{array}{l}\text { Jumlah } \\
\text { Individu }\end{array}$ & $\begin{array}{c}\text { Densitas } \\
\left.\text { Mutlak } \mathbf{( M}^{\mathbf{2}}\right)\end{array}$ & $\begin{array}{c}\text { Densitas } \\
\text { Relatif (\%) }\end{array}$ \\
\hline 1 & Cassia siamea, $L$ & 8 & 0,08 & 12,12 \\
\hline 2 & Tectona grandis, $L$ & 15 & 0,15 & 22,73 \\
\hline 3 & Swietenia macrophylla & 9 & 0,09 & 13,64 \\
\hline 4 & Acacia mangium, $L$ & 6 & 0,06 & 9,09 \\
\hline 5 & $\begin{array}{l}\text { Zyziphus mauritiana, } \\
\text { Dryand }\end{array}$ & 2 & 0,02 & 3,03 \\
\hline 6 & Mangifera indica, $L$ & 2 & 0,02 & 3,03 \\
\hline 7 & Schleichera oleasa, Merr & 3 & 0,03 & 4,54 \\
\hline 8 & Leucena lenccophalla & 2 & 0,02 & 3,03 \\
\hline 9 & Bombax ceiba, $L$ & 3 & 0,03 & 4,54 \\
\hline 10 & Ficus benjamina, $L$ & 2 & 0,02 & 3,03 \\
\hline 11 & Alstonia scholaris, $L$ & 5 & 0,05 & 7,58 \\
\hline 12 & $\begin{array}{l}\text { Casuarinas } \\
\text { junghuhyniana, Miq }\end{array}$ & 5 & 0,05 & 7,58 \\
\hline
\end{tabular}




\begin{tabular}{|c|c|c|c|c|}
\hline 13 & Zyziphus jujube, Mill & 4 & 0,04 & 6,06 \\
\hline & JUMLAH & $\mathbf{6 6}$ & $\mathbf{0 , 6 6}$ & $\mathbf{1 0 0}$ \\
\hline
\end{tabular}

Berdasarkan data pada tabel 7 menunjukkan bahwa jenis tumbuhan berkayu tingkat tiang yang mempunyai densitas tertinggi adalah Tectona grandis, $L$, Dengan nilai densitas $22,72 \%$, Kemudian diikuti oleh Swietenia macrophylla, Dengan nilai densitas 13,64 \%, Cassia siamea, $L$, Dengan nilai densitas 12,12 \%, Acacia mangium, $L$, Dengan nilai densitas 9,09 \%, Alstonia scholaris, L, Casuarinas junghuhyniana, Miq Dengan nilai densitas 7,58 $\%$, Zyziphus jujube, Mill, Dengan nilai densitas 6,06 \%, Leucena lenccophalla, Schleichera oleasa, Merr, Dengan nilai densitas 4,54 \%, Zyziphus mauritiana, Dryand, Mangifera indica, L, Leucena lenccophalla, Ficus benjamina, L, Dengan nilai densitas 3,03\%.

\section{Nilai Frekuensi Mutlak dan Frekuensi Relatif Jenis Tumbuhan Tingkat Tiang}

Hasil perhitungan frekuensi mutlak dan frekuensi relatif jenis tumbuhan tingkat tiang dapat di lihat pada tabel 8 .

Tabel 8. Nilai frekuensi mutlak dan frekuensi relatif jenis tumbuhan tingkat tiang di lokasi penelitian

\begin{tabular}{|c|c|c|c|c|}
\hline No & Jenis Tumbuhan & $\begin{array}{l}\text { Jumlah } \\
\text { Individu }\end{array}$ & $\begin{array}{c}\text { Frekuensi } \\
\text { Mutlak } \\
\left(\mathbf{M}^{2}\right)\end{array}$ & $\begin{array}{c}\text { Frekuensi } \\
\text { Relatif } \\
(\%)\end{array}$ \\
\hline 1 & Cassia siamea, $L$ & 8 & 0,26 & 3,00 \\
\hline 2 & Tectona grandis, $L$ & 15 & 0,13 & 1,50 \\
\hline 3 & Swietenia macrophylla & 9 & 0,46 & 5,30 \\
\hline 4 & Acacia mangium, $L$ & 6 & 0,6 & 6,90 \\
\hline 5 & Zyziphus mauritiana, Dryand & 2 & 0,8 & 9,20 \\
\hline 6 & Mangifera indica, $L$ & 2 & 0,86 & 9,90 \\
\hline 7 & Schleichera oleasa, Merr & 3 & 0,8 & 9,20 \\
\hline 8 & Leucena lenccophalla & 2 & 0,73 & 8,40 \\
\hline 9 & Bombax ceiba, $L$ & 3 & 0,8 & 9,20 \\
\hline 10 & Ficus benjamina, $L$ & 2 & 0,86 & 9,90 \\
\hline 11 & Alstonia scholaris, $L$ & 5 & 0,86 & 9,90 \\
\hline 12 & Casuarinas junghuhyniana, Miq & 5 & 0,73 & 8,40 \\
\hline \multirow[t]{2}{*}{13} & Zyziphus jujube, Mill & 4 & 0,8 & 9,20 \\
\hline & JUMLAH & 66 & 8,69 & 100 \\
\hline
\end{tabular}

Berdasarkan nilai frekuensi pada tabel 8 menunjukkan bahwa jenis tumbuhan tingkat tiang yang mempunyai nilai frekuensi tertinggi adalah Mangifera indica, L, Ficus benjamina, L, Alstonia scholaris, L, Dengan nilai frekuensi 9,90\%, Kemudian diikuti oleh Zyziphus mauritiana, Dryand, Schleichera oleasa, Merr, Bombax ceiba, L, Zyziphus jujube, Mill, 
Dengan nilai frekuensi 9,20\%, Leucena lenccophalla, Casuarinas junghuhyniana, Miq, Dengan nilai frekuensi 8,40 \%, Acacia mangium, L, Dengan nilai frekuensi 6,90 \%, Swietenia macrophylla, Dengan nilai frekuensi 5,30 \%, Cassia siamea, L, Dengan nilai frekuensi 3,00 $\%$, Tectona grandis, $L$, Dengan nilai frekuensi 1,50\%.

\section{Nilai Luas Basal Area Dan Luas Basal Area Relatif Jenis Tumbuhan Tingkat Tiang}

Hasil perhitungan luas basal area relatif jenis tumbuhan tingkat pohon di lokasi penelitian dapat di lihat pada tabel 9.

Tabel 9. Nilai perhitungan luas basal area relatif jenis tumbuhan tingkat Tiang di lokasi penelitian

\begin{tabular}{|c|c|c|c|c|}
\hline No & Jenis Tumbuhan & $\begin{array}{l}\text { Jumlah } \\
\text { individu }\end{array}$ & $\begin{array}{c}\text { Luas Basal } \\
\text { Area }\end{array}$ & $\begin{array}{l}\text { Luas Basal } \\
\text { Area Relatif }\end{array}$ \\
\hline 1 & Cassia siamea, $L$ & 8 & 17,85 & 7,52 \\
\hline 2 & Tectona grandis, $L$ & 15 & 28,73 & 12,10 \\
\hline 3 & Swietenia macrophylla & 9 & 17,85 & 7,52 \\
\hline 4 & Acacia mangium, $L$ & 6 & 20,33 & 8,57 \\
\hline 5 & Zyziphus mauritiana, Dryand & 2 & 9,61 & 4,05 \\
\hline 6 & Mangifera indica, $L$ & 2 & 15,54 & 6,55 \\
\hline 7 & Schleichera oleasa, Merr & 3 & 13,44 & 5,66 \\
\hline 8 & Leucena lenccophalla & 2 & 11,45 & 4,82 \\
\hline 9 & Bombax ceiba, $L$ & 3 & 17,85 & 7,52 \\
\hline 10 & Ficus benjamina, $L$ & 2 & 22,96 & 9,70 \\
\hline 11 & Alstonia scholaris, $L$ & 5 & 25,77 & 10,87 \\
\hline 12 & Casuarinas junghuhyniana, Miq & 5 & 20,33 & 8,57 \\
\hline \multirow[t]{2}{*}{13} & Zyziphus jujube, Mill & 4 & 15,54 & 6,55 \\
\hline & JUMLAH & 66 & 237,25 & 100 \\
\hline
\end{tabular}

Berdasarkan hasil perhitungan pada tabel 8 menunjukkan bahwa jenis tumbuhan berkayu tingkat tiang yang mempunyai nilai basal area relatif tertinggi adalah Tectona grandis, L, Dengan nilai basal area relatif $12,10 \%$, Kemudian diikuti oleh Alstonia scholaris, $L$, Dengan nilai basal area relatif $10,87 \%$, Ficus benjamina, L, Dengan nilai basal area relatif 9,70\%, Acacia mangium, L, Casuarinas junghuhyniana, Miq, Dengan nilai basal area relatif 8,57 \%, Swietenia macrophylla, Cassia siamea, L, Bombax ceiba, L, Dengan nilai basal area relatif 7,52 \%, Mangifera indica, L, Zyziphus jujube, Mill, Dengan nilai basal area relatif 6,55 $\%$, Schleichera oleasa, Merr, Dengan nilai basal area relatif 5,66 \%, Leucena lenccophalla, Dengan nilai basal area relatif 4,82 \%, Zyziphus mauritiana, Dryand, Dengan nilai basal area relatif $4,05 \%$.

\section{Indeks Nilai Penting (INP) Tingkat Tiang}

Hasil perhitungan indeks nilai penting jenis tumbuhan tingkat tiang dapat di lihat pada tabel 10 . 
Tabel 10. Hasil perhitungan indeks nilai penting jenis tumbuhan tingkat tiang di lokasi penelitian

\begin{tabular}{|l|l|c|c|c|c|}
\hline No & \multicolumn{1}{|c|}{ Jenis Tumbuhan } & DR & F R & LBAR & INP (\%) \\
\hline 1 & Cassia siamea, $L$ & 12,12 & 3,00 & 7,52 & 22,64 \\
\hline 2 & Tectona grandis, $L$ & 22,73 & 1,50 & 12,10 & 36,33 \\
\hline 3 & Swietenia macrophylla & 13,64 & 5,30 & 7,52 & 26,46 \\
\hline 4 & Acacia mangium, L & 9,09 & 6,90 & 8,57 & 24,56 \\
\hline 5 & Zyziphus mauritiana, Dryand & 3,03 & 9,20 & 4,05 & 16,28 \\
\hline 6 & Mangifera indica, $L$ & 3,03 & 9,90 & 6,55 & 19,48 \\
\hline 7 & Schleichera oleasa, Merr & 4,54 & 9,20 & 5,66 & 19,4 \\
\hline 8 & Leucena lenccophalla & 3,03 & 8,40 & 4,82 & 16,25 \\
\hline 9 & Bombax ceiba, $L$ & 5,54 & 9,20 & 7,52 & 21,26 \\
\hline 10 & Ficus benjamina, $L$ & 3,03 & 9,90 & 9,70 & 22,63 \\
\hline 11 & Alstonia scholaris, L & 7,58 & 9,90 & 10,87 & 28,35 \\
\hline 12 & Casuarinas junghuhyniana, Miq & 7,58 & 8,40 & 8,57 & 24,55 \\
\hline 13 & Zyziphus jujube, Mill & 6,06 & 9,20 & 6,55 & 21,81 \\
\hline & JUMLAH & $\mathbf{1 0 0}$ & $\mathbf{1 0 0}$ & $\mathbf{1 0 0}$ & $\mathbf{3 0 0}$ \\
\hline
\end{tabular}

Berdasarkan hasil perhitungan indeks nilai penting pada tabel 10 dapat diketahui bahwa jenis tumbuhan berkayu tingkat tiang yang memiliki indeks nilai penting (INP) tertinggi sampai terendah adalah Tectona grandis, L, 36,33\%, Alstonia scholaris, L, 28,35 $\%$, Swietenia macrophylla 26,46 \%, Acacia mangium, L, 24,56 \%, Casuarinas junghuhyniana, Miq 24,55 \%, Cassia siamea, L, 22,64 \%, Ficus benjamina, L, 22,63\%, Zyziphus jujube, Mill, 21,81 \%, Bombax ceiba, L, 21,26 \%, Mangifera indica, L, 19,48 \%, Schleichera oleasa, Merr, 19,4 \%, Zyziphus mauritiana, Dryand, 16,28 \%, Leucena lenccophalla, 16,25\%.

\section{KESIMPULAN DAN SARAN}

\section{Kesimpulan}

Berdasarkan hasil penelitian pada kawasan hutan lindung Oereu, Desa Bani-Bani, Kecamatan Io Kufeu, maka penulis dapat menyimpulkan bahwa:

1. Jenis tumbuhan tingkat pohon dan tiang yang terdapat di kawasan hutan Lindung Oereu sebanyak 13 jenis, yang terdiri dari 11 famili dengan jumlah 196 individu.

2. Komposisi vegetasi yang terdapat di hutan lindung Oereu dilihat dari kerapatan spesies dan indeks nilai penting (INP) pada fase Pohon didominansi oleh jenis Tectona Grandis. $L, 35 \mathrm{ind} / \mathrm{m}^{2}$ dengan INP sebesar 57,35\%. Sedangkan pada Tiang didominansi oleh Tectona Grandis. L, $15 \mathrm{ind} / \mathrm{m}^{2}$ dengan INP sebesar 36,33\%.

\section{Saran}

Struktur dan komposisi vegetasi tingkat pohon dan tiang mempunyai peranan yang sangat penting dalam mempertahankan kestabilan/keseimbangan hutan, khususnya di 
kawasan hutan lindung Oereu agar tetap terjaga kestabilannya. Oleh karena itu penulis dapat menyarankan kepada:

1. Pemerintah kabupaten malaka khususnya Dinas Kehutanan agar tetap menjaga dan melestarikan jenis-jenis hutan lindung yang ada di Kabupaten Malaka, khususnya Hutan Lindung Oereu dengan mengadakan penghijauan (Reboisasi).

2. Masyarakat Desa Bani-Bani, khususnya masyarakat yang berada di sekitar kawasan hutan lindung Oereu, supaya tidak menebang hutan sembarangan karena hutan tersebut sangat bermanfaat bagi kehidupan masyarakat.

3. Bagi mahasiswa/i sebagai bahan informasi dalam penelitian lebih lanjut, terutama yang berminat dalam penelitian ekologi hutan khususnya tentang jenis tumbuhan tingkat pancang, dan anakan.

\section{DAFTAR RUJUKAN}

Anonimus, 1999. Undang-undang No 41 Tahun 1999 Tentang Ketentuan Pokok Hutan.Jakarta

Astuti S.S, 2009. Struktur dan Komposisi Vegetasi Pohon dan Pole di Sekitar Jalur Wisata Taman Wisata Alam Sicikeh-Cikeh Kabupaten Dairi Sumatera Utara.

BPS. 2011. Kabupaten Malaka dalam angka malaka.

Dian, 2007. Biologi untuk SMA kelas X. Jakarta: Erlangga.

Endang, 2013. Pengatar Ilmu Kehutanan. Taman Kencana Bogor: PTIPB press.

Fachrul, F. M., 2008. Metode Sampling Bioekologi. Bumi aksara. Jakarta.

Indriyanto, 2006. Ekologi Hutan. Yogyakarta: PT. Bumi Aksara.

Indriyanto, 2008. Pengantar Budidaya Hutan. Jakarta: PT. Bumi Aksara.

Istamar,2002. IPA Biologi untuk SLTP Kelas 1. Malang: Erlangga

Marsono, D. 1997. Potensi Dan Kondisi Hutan Tropika Basah di Indonesia. Yogyakarta. 